\title{
DESKRIPSI KEMANDIRIAN BELAJAR DALAM PEMBELAJARAN MATEMATIKA SMP
}

\author{
Muh Rizal Kidjab ${ }^{1 *}$, Sumarno Ismail ${ }^{2}$, Abdul Wahab Abdullah ${ }^{3}$ \\ 1,2,3 Jurusan Matematika, Universitas Negeri Gorontalo, Bone Bolango 96119, Indonesia \\ *Penulis Korespondensi. Email: rizalkidjab12@gmail.com
}

\begin{abstract}
Abstrak
Penelitian ini merupakan penelitian deskriptif dengan pendekatan kualitatif yang bertujuan untuk menggambarkan kemandirian belajar dalam pembelajaran matematika SMP. Indikator yang digunakan untuk menggambarkan kemandirian belajar matematika antara lain: (1) mampu bertanggung jawab, (2) memiliki kedisiplinan, (3) mampu bekerja sendiri, (4) memiliki inisiatif, dan (5) memiliki kepercayaan diri. Instrumen pengumpulan data terdiri dari angket dan wawancara untuk memperdalam informasi mengenai kemandirian belajar dalam pembelajaran matematika SMP. Subjek penelitian adalah siswa SMP Negeri 1 Kabila yang diambil berdasarkan teknik simple random sampling. Analisis data yang dilakukan meliputi reduksi data, penyajian data, dan penarikan kesimpulan/verifikasi. Berdasarkan hasil penelitian diketahui bahwa persentasi kemandirian belajar dalam pembelajaran matematika dengan predikat tinggi sebesar 17,39\%, predikat sedang sebesar $56,52 \%$, dan predikat rendah sebesar $26,09 \%$. Selanjutnya diketahui bahwa faktor-faktor yang paling dominan mempengaruhi kemandirian belajar dalam pembelajaran matematika antara lain, ketidakmampuan siswa dalam menilai diri sendiri serta kurangnya inisiatif diri.
\end{abstract}

Kata Kunci: Kemandirian Belajar; Pembelajaran Matematika; Matematika SMP

\section{Pendahuluan}

Pendidikan adalah suatu upaya sadar yang dilakukan guna mencerdaskan bangsa. Menurut Komara [1] sesuai dengan yang termaktub dalam Undang-undang sistem pendidikan nasional Republik Indonesia No. 20 Tahun 2003 Bab II Pasal 3 yaitu pendidikan nasional bertujuan untuk berkembangnya potensi peserta didik agar menjadi manusia yang beriman dan bertaqwa kepada Tuhan Yang Maha Esa, berakhlak mulia, sehat, berilmu, cakap, kreatif, mandiri dan menjadi warga negara yang demokratis serta bertanggung jawab. Dalam konteks pendidikan, kemandirian sangat penting untuk dikembangkan pada siswa guna memperlancar proses belajar mengajar, sehingga tujuan pendidikan yang sudah ditentukan dapat tercapai dengan baik. Hal tersebut sesuai dengan Permendikbud Nomor 66 Tahun 2013 tentang Standar Penilaian Pendidikan bahwa penilaian hasil belajar peserta didik mencakup kompetensi sikap, pengetahuan, dan keterampilan.

Sejalan dengan perkembangan ilmu pengetahuan dan teknologi (IPTEK) yang makin maju diduga semakin memudahkan pemenuhan kebutuhan anak. Maksudnya, apa saja yang dibutuhkan kebanyakan dapat terpenuhi sehingga membuat anak berpola pikir pragmatis, yaitu segala macam kebutuhannya ingin selalu dapat terpenuhi. Realita dalam kehidupan masyarakat akhir-akhir ini memang demikian karena banyak anakanak yang menampakkan tanda- tanda kurang memiliki kemandirian belajar. Dalam hal ini, Nuridawani [2] mengemukakan bahwa matematika merupakan salah satu disiplin ilmu pasti yang mendasari perkembangan teknologi modern. Hal ini disebabkan karena matematika mempunyai peranan penting dalam berbagai disiplin ilmu lain dan mempunyai pengaruh besar dalam memajukan kemajuan daya pikir manusia.

Kemandirian dibutuhkan untuk menunjang agar proses pembelajaran dapat berjalan dengan baik. Kemandirian belajar adalah suatu sikap siswa yang memiliki karakteristis berinisiatif belajar, menetapkan tujuan belajar, memonitor, mengatur dan mengontrol kinerja atau belajar, memandang kesulitan sebagai tantangan, mencari dan memanfatkan sumber belajar yang relevan, memilih dan menerapkan strategi belajar, mengevaluasi proses dan hasil belajar, serta memiliki self-concept (konsep diri). Dengan memiliki kemandirian belajar siswa memiliki tujuan yang jelas, dapat menilai diri sendiri, mempertimbangkan kemampuan belajar, seperti pandangan dan kemampuan yang tinggi terhadap dirinya, serta menilai pembelajaran. Tantangan bagi guru dalam proses pembelajaran salah satunya adalah menumbuhkan sikap kemandirian belajar dari peserta didik agar tidak terjadi perilaku yang menyimpang dalam proses pembelajaran. Berdasarkan pengalaman peneliti pada saat mengikuti Program Pengalaman Lapangan (PPL) 
mahasiswa yang diselenggarakan oleh Lembaga Pengembangan Pendidikan dan Pembelajaran (LP3) Universitas Negeri Gorontalo di SMP Negeri 1 Kabila, ditemukan beberapa hal yang tidak mencerminkan sikap mandiri yaitu pada saat peneliti memberikan latihan ataupun ulangan harian, diantaranya adalah siswa saling meniru jika sudah diberikan latihan ataupun soal-soal ulangan, mereka punya banyak cara untuk mengelak agar dapat meniru pekerjaan temannya.

Hasil observasi di SMP Negeri 1 Kabila menunjukkan bahwa pada saat pelajaran berlangsung kebanyakan siswa saling meniru pekerjaan temannya. Hasil observasi ini relevan dengan pernyataan guru mata pelajaran matematika di sekolah itu, dimana salah satu masalahnya adalah siswa saling meniru jika diberikan latihan ataupun soal-soal ulangan, mereka sampai punya banyak cara agar tidak diketahui guru untuk meniru pekerjaan temannya, beberapa kali pula pada saat akan dikumpul tugas yang diberikan masih ada siswa yang meminta jawaban tugas tersebut untuk disalinnya. Mata pelajaran matematika diberikan untuk membekali peserta didik dengan kemampuan berpikir logis, analitis, sistematis, kritis, dan kreatif, serta kemampuan bekerjasama. Namun, hal tersebut kebanyakan siswa belum mampu mengaplikasikannya karena banyak siswa yang tidak mau terlalu memeras pikirannya untuk mengerjakan soal yang diberikan. Sehingga pengujian penguasaan materi yang diajarkan di SMP membuat siswa tidak memandang kesulitan sebagai tantangan.

Memperhatikan beberapa hal di atas dan kenyataan yang ditemukan serta mengingat pentingnya kemandirian belajar dalam pembelajaran matematika, dilakukan penelitian untuk mendeskripsikan Kemandirian Belajar dalam Pembelajaran Matematika di SMP Negeri 1 Kabila.

\section{Metode Penelitian}

Penelitian ini dilaksanakan di SMP Negeri 1 Kabila pada Semester Ganjil Tahun Ajaran 2017/2018 dalam waktu 3 bulan dengan melibatkan 25 Siswa sebagai sampel yang dipilih dengan teknik simple random sampling. Metode yang digunakan adalah metode penelitian deskriptif untuk menggambarkan kemandirian belajar dalam pembelajaran matematika SMP. Instrumen yang digunakan dalam penelitian ini adalah angket untuk mengumpul data yang dikembangkan dalam bentuk pernyataan, dan wawancara. wawancara digunakan untuk mengumpul data dalam bentuk pertanyaan. Variabel yang digunakan dalam penelitian ini hanya ada satu variabel yakni tentang kemandirian belajar dalam pembelajaran matematika.

Secara operasional kemandirian belajar yang dimaksud dalam penelitian ini adalah kemandirian belajar siswa kelas VIII SMP Negeri 1 Kabila dalam pembelajaran matematika, dimana indikator yang digunakan untuk mengukur kemandirian belajar dalam pembelajaran matematika, yakni: (1). Mampu bertanggung jawab, (2). Memiliki kedisiplinan, (3). Mampu bekerja sendiri, (4). Memiliki inisiatif, dan (5). Memiliki kepercayaan diri.

\section{Pembahasan}

\subsection{Deskripsi Hasil Penelitian}

Berdasarkan hasil pekerjaan siswa pada lembar jawaban angket diperoleh gambaran kemandirian belajar dalam pembelajaran matematika untuk setiap butir pernyataan yang dinilai berdasarkan analisis statistik parametrik yang direduksi dan disajikan sesuai dengan indikator kemandirian belajar dalam pembelajaran matematika. Data tersebut dapat dilihat pada sajian data berdasarkan indikator-indikator berikut:

\subsubsection{Mampu Bertanggung Jawab}

Mampu bertanggung jawab adalah suatu sikap dimana siswa mampu untuk menyadari akan tingkah laku atau perbuatannya yang disengaja maupun yang tidak disengaja. Dalam proses pembelajaran, siswa diharapkan mampu bertanggung jawab terhadap dirinya sendiri maupun orang lain. Sehingga, dalam kesehariannya siswa tersebut mampu untuk menanggung tugas-tugas yang diberikan padanya. Diperoleh gambaran kemandirian belajar dalam pembelajaran matematika terkait indikator mampu bertanggung jawab dari masing-masing predikat pada Gambar 1. 


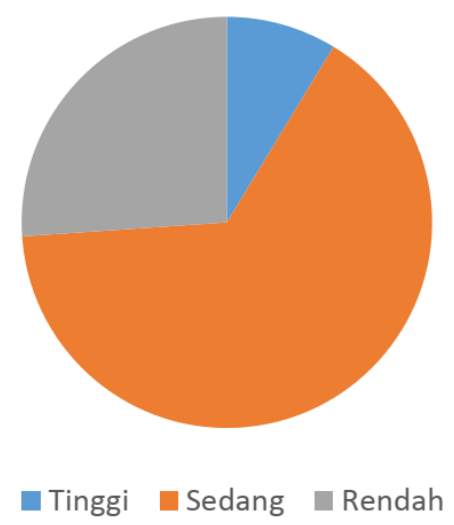

Gambar 1. Persentase siswa pada indikator mampu bertanggung jawab

Gambar 1 menunjukkan bahwa siswa yang tergolong dalam predikat tinggi berjumlah 2 orang dengan persentasi $8,70 \%$. Kedua, untuk siswa yang tergolong dalam predikat sedang berjumlah 15 orang dengan persentasi $65,22 \%$. Dan yang terakhir, siswa yang tergolong dalam predikat rendah berjumlah 6 orang dengan persentasi $26,09 \%$.

\subsubsection{Memiliki Kedisiplinan}

Kedisiplinan ialah suatu sikap dimana siswa dapat mengaktualisasikan diri kearah yang lebih baik. Kedisiplinan berarti suatu sikap yang mengarah pada perilaku seseorang untuk bertindak berdasarkan ketentuan dan aturan yang telah ditentukan bersama, dengan pertimbangan atas kepentingan bersama. Dalam pembelajaran itu sendiri, siswa dikondisikan untuk memiliki kedisiplinan. Sehingga, siswa tersebut mampu menjadikan dirinya pribadi yang konsisten dalam situasi dan kondisi apapun. Persentase siswa pada indikator kedisiplinan dinyatakan pada Gamba 2.

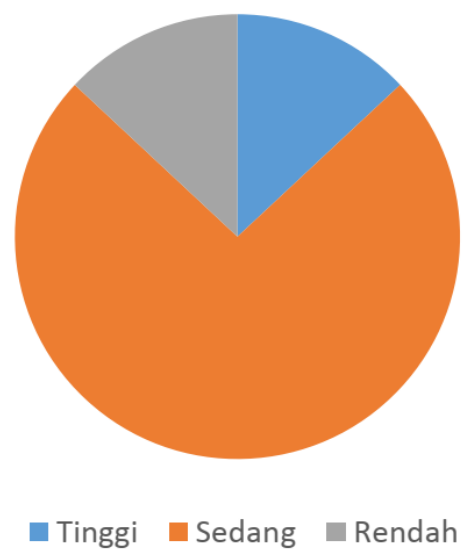

Gambar 2. Persentase siswa pada indikator kedisiplinan

Gambar 2 memberikan gambaran kemandirian belajar dalam pembelajaran matematika terkait indikator memiliki kedisiplinan dari masing-masing predikat. Yang pertama, siswa yang tergolong dalam predikat tinggi berjumlah 3 orang dengan persentasi 13,04\%. Kedua, untuk siswa yang tergolong dalam predikat sedang berjumlah 17 orang dengan persentasi $73,91 \%$. Dan yang terakhir, siswa yang tergolong dalam predikat rendah berjumlah 3 orang dengan persentasi 13,04\%.

\subsubsection{Mатри Bekerja Sendiri}

Mampu bekerja sendiri ialah ialah suatu sikap kecenderungan siswa untuk melakukan sesuatu yang diinginkannya tanpa bantuan dari orang lain. Dalam pembelajaran, siswa yang mampu bekerja sendiri akan 
memilih sikap berusaha terlebih dahulu sebelum meminta bantuan orang lain. Persentase siswa pada indikator kempuan bekerja sendiri disajikan pada Gambar 3.

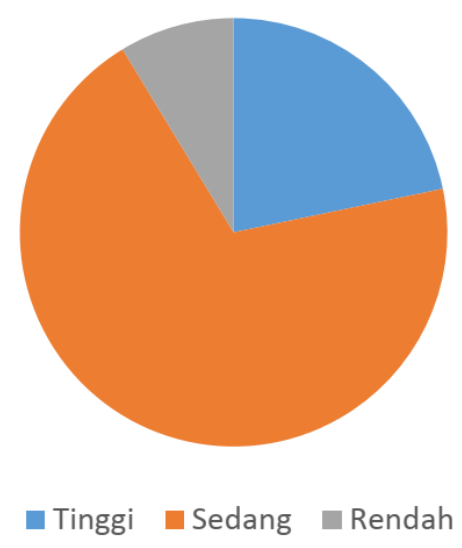

Gambar 3. Persentase siswa pada indikator kemampuan bekerja mandiri

Gambar 3 memberi gambaran kemandirian belajar dalam pembelajaran matematika terkait indikator mampu bekerja sendiri dari masing-masing predikat. Yang pertama, siswa yang tergolong dalam predikat tinggi berjumlah 5 orang dengan persentasi $21,74 \%$. Kedua, untuk siswa yang tergolong dalam predikat sedang berjumlah 16 orang dengan persentasi $69,57 \%$. Dan yang terakhir, siswa yang tergolong dalam predikat rendah berjumlah 2 orang dengan persentasi 8,70\%.

\subsubsection{Memiliki Inisiatif}

Adanya inisiatif dalam diri seorang siswa, artinya siswa tersebut memiliki kemauan dalam diri untuk mencapai suatu yang diinginkannya. Dalam pembelajaran, ketika siswa yang memiliki inisiatif dalam dirinya, siswa tersebut dapat mencari solusi dari setiap masalah serta bagaimana cara yang ditempuhnya untuk menyelesaikan masalah tersebut tanpa tergantung dari orang lain. pesentase siswa pada indikator inisiatif ditampilkan pada Gambar 4.

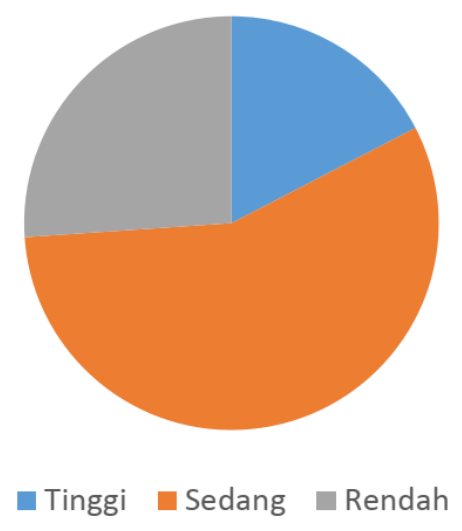

Gambar 4. Persentase siswa pada indikator memiliki inisiatif

Gambar 4 memberi gambaran kemandirian belajar dalam pembelajaran matematika terkait indikator memiliki inisiatif dari masing-masing predikat. Yang pertama, siswa yang tergolong dalam predikat tinggi berjumlah 4 orang dengan persentasi $17,39 \%$. Kedua, untuk siswa yang tergolong dalam predikat sedang berjumlah 13 orang dengan persentasi 56,52\%. Dan yang terakhir, siswa yang tergolong dalam predikat rendah berjumlah 6 orang dengan persentasi 26,09\%. 


\subsubsection{Memiliki Kepercayaan Diri}

Kepercayaan diri adalah keadaan mental peserta didik dalam menghadapi situasi pembelajaran matematika yang semakin menantang dengan keyakinan kuat pada kemampuan yang dimilikinya sehingga tidak perlu bergantung pada orang lain dan tidak cemas dalam melakukan sesuatu. Persentase siswa pada indikator kepercayaan diri ditampilkan pada Gambar 5.

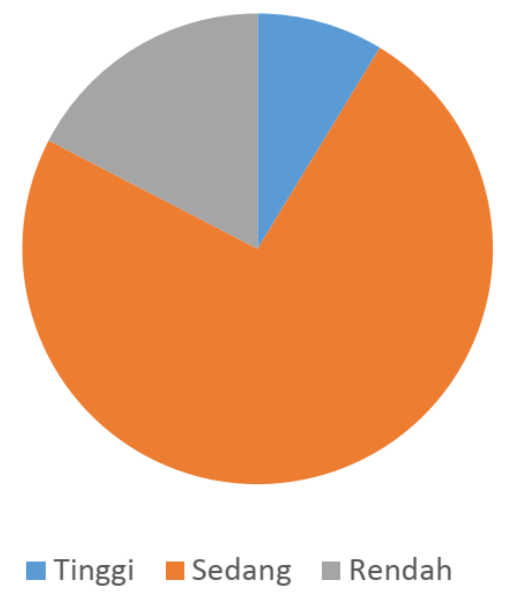

Gambar 5. Persentase siswa pada indikator kepercayaan diri

Gambar 5 menunjukkan kemandirian belajar dalam pembelajaran matematika terkait indikator memiliki kepercayaan diri dari masing-masing predikat. Yang pertama, siswa yang tergolong dalam predikat tinggi berjumlah 2 orang dengan persentasi $8,70 \%$. Kedua, untuk siswa yang tergolong dalam predikat sedang berjumlah 17 orang dengan persentasi $73,91 \%$. Dan yang terakhir, siswa yang tergolong dalam predikat rendah berjumlah 4 orang dengan persentasi 17,39\%.

\subsubsection{Kemandirian Belajar dalam Pembelajaran Matematika Secara Umum}

Kemandirian belajar dalam pembelajaran matematika merupakan suatu sikap siswa yang meliputi suatu keadaan dimana siswa tersebut mampu bertanggung jawab, memiliki kedisiplinan, mampu bekerja sendiri, memiliki inisiatif, serta memiliki kepercayaan diri. Kemandian belajar dalam pembelajaran matematika secara umum merupakan kemandirian belajar yang secara keseluruhan berdasarkan semua indikator. Persentase siswa pada indikator ini ditampilkan pada Gambar 6.

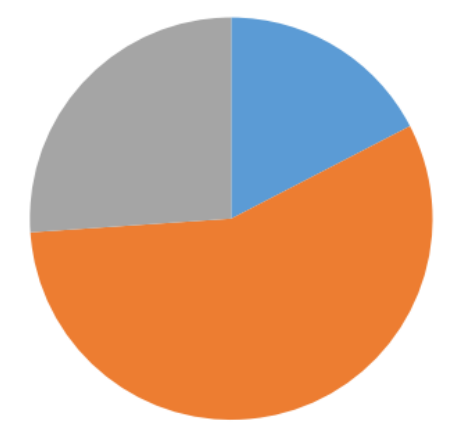

- Tinggi $\quad$ Sedang $\square$ Rendah

Gambar 6. Indikator kemandirian belajar dalam pembelajaran matematika

Gambar 6 menunjukkan kemandirian belajar dalam pembelajaran matematika secara umum. Yang pertama, siswa yang tergolong dalam predikat tinggi berjumlah 4 orang dengan persentasi $17,39 \%$. Kedua, 
untuk siswa yang tergolong dalam predikat sedang berjumlah 13 orang dengan persentasi 56,52\%. Dan yang terakhir, siswa yang tergolong dalam predikat rendah berjumlah 6 orang dengan persentasi 26,09\%.

\subsection{Pembahasan}

Berdasarkan analisis pada angket maupun wawancara, terdapat beberapa faktor yang mempengaruhi setiap indikator kemandirian belajar dalam pembelajaran matematika, diantaranya sebagai berikut:

\subsubsection{Ketidakmampuan dalam menilai diri sendiri}

Salah satu yang menyebabkan kemandirian belajar dalam pembelajaran matematika tergolong sedang adalah ketidakmampuan siswa dalam menilai diri sendiri. Dalam proses pembelajaran, siswa dituntut untuk mampu mengelola kemampuan diri sendiri sehingga tanpa harus bergantung pada orang lain. Oleh karena siswa hanya mengandalkan bantuan dari orang lain, menyebabkan siswa tersebut tidak lagi mengembangkan kemampuan yang dimiliki utamanya kemampuan dalam bekerja sendiri. Hal tersebut sejalan dengan yang dikemukakan oleh Ranti [3] bahwa kemandirian dalam belajar berarti siswa memiliki kesadaran sendiri untuk belajar, mampu menentukan sendiri langkah-langkah yang harus diambil dalam belajar, mampu memperoleh sumber belajar sendiri, dan melakukan kegiatan evaluasi diri serta refleksi atas kegiatan pembelajaran yang sudah dilakukan. Pendapat tersebut, senada dengan yang dikemukakan oleh Nuridawani [2] bahwa dengan memiliki kemandirian belajar, siswa akan mempunyai tujuan yang jelas, dapat menilai diri sendiri, mempertimbangkan kemajuan belajar, seperti pandangan dan kepercayaan yang tinggi tentang kemampuan dirinya, menilai pembelajaran, faktor yang berpengaruh dalam belajar, dan antisipasi dampak (self-efficacy) selama proses pembelajaran.

Selanjutnya, menurut Fitriana [4] siswa yang memiliki kemandirian belajar yang tinggi akan berusaha menyelesaikan latihan atau tugas yang diberikan oleh guru dengan kemampuan yang dimilikinya, sebaliknya siswa yang memiliki kemandirian belajar yang rendah akan tergantung pada orang lain.

\subsubsection{Kurangnya inisiatif diri}

Kurangnya inisiatif diri siswa tentu akan berpengaruh pada proses pembelajarannya. Hal ini karena, inisiatif yang dimiliki siswa dapat memberi dorongan pada diri untuk untuk mencari solusi dari setiap masalah serta bagaimana cara yang ditempuhnya untuk menyelesaikan masalah tersebut tanpa tergantung dari orang lain. Jika, siswa memiliki kemauan diri untuk bersikap demikian, maka akan mendukung siswa dalam pembelajaran matematika. Hal tersebut sejalan dengan yang dikemukakan oleh Fahradina [5] bahwa tingkat kemandirian belajar siswa dapat ditentukan berdasarkan seberapa besar inisiatif dan tanggung jawab siswa untuk berperan aktif dalam hal perencanaan belajar, proses belajar maupun evaluasi belajar. Semakin besar peran aktif siswa dalam berbagai kegiatan tersebut, mengindikasikan bahwa siswa tersebut memiliki tingkat kemandirian belajar yang tinggi.

\section{Kesimpulan}

Berdasarkan hasil penelitian dan pembahasan yang telah diuraikan sebelumnya, kemandirian belajar dalam pembelajaran matematika terbagi atas 3 predikat yakni predikat tinggi dengan persentasi 17,39\%, predikat sedang dengan persentasi 56,52 \% dan predikat rendah dengan persentasi 26,09 \%. Dari ketiga predikat tersebut secara umum siswa hanya mampu memenuhi sebagian indikator kemandirian belajar dalam pembelajaran matematika yaitu indikator mampu bertanggung jawab, indikator memiliki kedisiplinan, indikator memiliki inisiatif, serta.

\section{Referensi}

[1] I.B. Komar, "Hubungan antara Kepercayaan Diri dengan Prestasi Belajar dan Perencanaan Karir Siswa", Jurnal Psikopedagogia, Vol. 5, No. 1, pp. 1-10, 2016.

[2] N. Nuridawani, S. Munzir, dan S. Saiman, "Peningkatan Penalaran Matematis dan Kemandirian Belajar Siswa Madrasah Tsanawiah (MTs) Melalui Pendekatan Contextual Teaching and Learning (CTL)", Jurnal Didaktik Matematika, Vol. 2, No.2, pp. 1-13, 2015. 
[3] G.R. Ranti, I. Budiarti, dan B.N. Trisna, "Pengaruh Kemandirian Belajar (Self Regulated Learning) terhadap Hasil Belajar Mahasiswa Pada Mata Kuliah Struktur Aljabar", Jurnal Pendidikan Matematika, Vol. 3, No. 1, pp. 10-21, 2017.

[4] L. Fitriana, "Pengaruh Model Pembelajaran Cooperative Tipe Group Investigation (GI) dan Stad terhadap Prestasi Belajar Matematika Ditinjau dari Kemandirian Belajar Siswa, Tesis, Universitas Sebelas Maret, 2010.

[5] N. Fahradina, B.I. Ansari, dan S. Saiman, "Peningkatan Kemampuan Komunikasi Matematis dan Kemandirian Belajar Siswa SMP dengan Menggunakan Model Investigasi Kelompok", Jurnal Didaktik Matematika, Vol. 1, No. 1, 2014. 